CASE REPORTS

\title{
Hypernatremia in breast-fed infants due to elevated breast milk sodium
}

\author{
JOHN M. PETERS, DO
}

The author describes severe hypernatremic dehydration in a 12-day-old, breast-fed infant. The mother's breast milk sodium level at the 13th day of the infant's life was $47 \mathrm{mEq} / \mathrm{L}$, more than three times normal value. At the 30th day, the mother's breast milk sodium level was $16 \mathrm{mEq} / \mathrm{L}$, still more than twice the normal value. To the author's knowledge, this is the first time in a case of this type that the breast milk sodium value of the mother has been followed this late in the infant's life. Results are consistent with the hypothesis that delayed maturation of breast milk composition is of central importance in this condition. A search of the literature reveals that the mothers of these babies fit a clinically distinct profile. Elevated breast milk sodium with hypernatremic dehydration is a cause of significant morbidity in some breast-fed infants. The pathogenesis of this condition and the implications for its prevention are discussed.

Hypernatremia, dehydration, cachexia, and failure to thrive in breast-fed infants have been adequately described in several reports dating back to the $1970 \mathrm{~s} .{ }^{1}$ Case reports of infants with hypernatremic dehydration in association with elevated breast milk sodium content first appeared in the literature in $1980 .{ }^{2}$ Since then, several more cases have been described. $1,3-5$

This case report reviews the composition of normal breast milk, discusses mechanisms leading to the production of abnormal breast milk, and analyzes the relationship of this condition to the abnormal sweat electrolytes seen in cystic fibrosis.
Finally, the report presents the clinical profile of mothers and infants affected by this condition as well as the implications for office management of the infant-mother breast-feeding dyad.

\section{Report of case}

A 12-day-old female infant was referred to Children's Hospital of Michigan (CHM) from another institution for management of severe dehydration. She was the term product of a 25-year-old primigravid married woman who had received regular prenatal care. No abnormalities of either the gestation or the delivery of the patient were reported. Birth weight was $4.03 \mathrm{~kg}$ (95th percentile), and the mother and child were sent home when the child was 48 hours of age and weighed $3.86 \mathrm{~kg}$.

Before admission, the infant was characterized by the parents as being able to follow objects through a 90 degree arc but not yet possessing a social smile. The infant was breast-fed exclusively and was reported to be doing well until 4 days before admission when she began crying after feedings and seemed to nurse for shorter periods of time than before. Three days before admission, she was taken to her private physician, who observed no abnormal physical findings and prescribed Mylicon drops (Stuart Pharmaceuticals) for "colic." By one day before admission, the infant had become "fussy" and had screaming episodes that would last for 5 to $10 \mathrm{sec}-$ onds. These were accompanied by clenching of the fists and flexing of the legs onto the lower abdomen. Additionally, she began passing loose green stools and having episodes of bilious, nonprojectile vomiting.

When seen by her private physician the next morning, she had gasping respirations and a heart rate of 80 beats per minute; she was transferred immediately to the referral hospital. There, she was found to be in respiratory distress; she was considerably dehydrated and had no obtainable blood pressure. Her pulse rate was 90 per minute and her temperature (mode of assessment unknown) was $32.8^{\circ} \mathrm{C}$. The patient was immediately intubated endotracheally, and a femoral venous cutdown catheter was placed for intravenous administra- 
tion of $5 \%$ dextrose and $9 \%$ normal saline, $15 \mathrm{~mL} / \mathrm{kg}$ of body weight. She was transported via helicopter back to the CHM pediatric intensive care unit. Initially, laboratory values for serum at the referral hospital included sodium, $176 \mathrm{mEq} / \mathrm{L}$; potassium, $7.4 \mathrm{mEq} / \mathrm{L}$; chloride, 110 $\mathrm{mEq} / \mathrm{L}$, and carbon dioxide content, $9 \mathrm{mEq} / \mathrm{L}$. The BUN level was $94 \mathrm{mg} / \mathrm{dL}$; WBC count, $22,900 / \gamma \mathrm{L}$, and hemoglobin, $16.1 \mathrm{~g} / \mathrm{dL}$.

On admission to CHM, the infant weighed $3.2 \mathrm{~kg}$ (25th percentile). She had minimal spontaneous respirations above the ventilator, a pulse rate of 168 per minute, blood pressure of $54 \mathrm{~mm} \mathrm{Hg}$ palpable systolic, and a rectal temperature of $35^{\circ} \mathrm{C}$. Physical examination revealed very poor skin turgor with tenting; dry, sunken eyes; and an anterior fontanelle that was grossly depressed by nearly $2.5 \mathrm{~cm}$ from the skull surface. Air exchange with ventilatory assistance was excellent; no adventitious sounds were heard. Cardiac examination revealed no murmurs. The abdomen had hyperactive bowel sounds, and it was nontender and nondistended, with no masses, guarding, or rebound tenderness.

There was no visceromegaly, but the anterior abdominal wall had a cyanotic hue. The infant had normal female external genitalia, and the anal orifice was patent. She had generalized hypotonia and made little spontaneous movement. Deep tendon reflexes were decreased, but symmetric.

Admission laboratory values for serum at $\mathrm{CHM}$ included: sodium, $169 \mathrm{mEq} / \mathrm{L}$; carbon dioxide content, 8.5 $\mathrm{mEq} / \mathrm{L}$; serum calcium, $8.2 \mathrm{mg} / \mathrm{dL}$; serum phosphorus, $15.3 \mathrm{mg} / \mathrm{dL}$; creatinine, $2.7 \mathrm{mg} / \mathrm{dL}$. The BUN level was $80 \mathrm{mg} / \mathrm{L}$. Prothrombin time, partial thromboplastin time, thrombin time, and platelet count were all within normal limits. Cerebrospinal fluid and blood cultures were obtained and were ultimately sterile. Roentgenologic studies of the chest were essentially normal except for a small cardiac silhouette; flat-plate abdominal x-ray films and a limited upper gastrointestinal series performed in the pediatric intensive care unit revealed no pneumatosis, perforation, malrotation, volvulus, or intussusception.

Findings of renal ultrasonography and renal scintography performed the next day were consistent with bilateral renal vein thrombosis. The serum antidiuretic hormone level at the 18th hour of the child's hospital stay was $5.9 \mathrm{pg} / \mathrm{mL}$ (normal, 0-6.0 pg/mL), with serum osmolality of $310 \mathrm{~m} 0 \mathrm{sm} / \mathrm{kg}$. A serum lactate level measured at the 22 nd hour of the child's admission was 17.5 $\mathrm{mg} / \mathrm{dL}$ (normal, 5-20.0 mg/dL), and a serum pyruvate level measured at the same time was $1.21 \mathrm{mg} / \mathrm{dL}$ (normal, 0.3-1.00 mg/dL).

On arrival at CHM, the child initially had required a total of $30 \mathrm{~mL} / \mathrm{kg}$ of intravenous colloid to achieve stabilization of vital signs. Though her sunken fontanelle and skin tenting gradually diminished over the first 24 hours of hospitalization, the infant did not have urine output until 48 hours following admission. At that time, urinalysis revealed a specific gravity of 1.012 , a pH of
8.0 , proteinuria $(+2)$, large blood, and 2 to 5 RBCs per high-power field.

The infant showed evidence of polyuria and sodiumwasting renal tubular dysfunction during this time. She required serial adjustments in intravenous fluid administration to maintain acceptable serum electrolyte levels and hydration status. The typical fluid given intravenously during this period was dextrose and water with $120 \mathrm{mEq} / \mathrm{L}$ of sodium chloride and $30 \mathrm{mEq} / \mathrm{L}$ of potassium chloride.

The infant passed watery, bloody stools during the first 5 days of her hospital stay. As this was believed to represent an ischemic gastrointestinal insult stemming from the patient's initial presentation, she was kept on a nothing-by-mouth restriction for the first 12 days at CHM. Renal function parameters had improved by the 5 th day of hospitalization to the point where intravenous hyperalimentation containing $10 \%$ dextrose and appropriate electrolyte concentrations could be started.

By the 12th day of hospitalization, oral feedings via nasogastric tube were started with full-strength Similac PM 60/40 formula. An occupational therapist worked daily with the child on sucking and oromotor skills, which improved slowly. Weight at this time was $4.0 \mathrm{~kg}$ (75th percentile)

Despite careful intravenous fluid administration, the patient had generalized tonic-clonic seizures within the first 12 hours of her hospital course. Serial EEGs displayed patterns of activity consistent with severe diffuse encephalopathy. Physical therapy was used continually throughout the infant's hospitalization. At discharge (patient age, 36 days), the infant had generalized hypotonia, most markedly in the right upper extremity. Sucking was good, but feeding was accompanied by frequent regurgitation. Though the infant would focus on faces and respond to a bell rung close to her ear, she would now follow objects only intermittently and could not lift her head from a prone position.

The infant was discharged after a 24-day hospitalization at a weight of $4.1 \mathrm{~kg}$. She was placed on a regimen of phenobarbital ( $4 \mathrm{mg} / \mathrm{kg} /$ day) for the seizure disorder, with instructions that she be fed Similac PM 60/40 formula ( $100 \mathrm{~mL} / \mathrm{kg} /$ day). The formula was given as scheduled nipple feedings, and the mother was instructed to feed any unfinished portion via gavage in order to meet this goal. At that time, laboratory values for serum were: sodium, $141 \mathrm{mEq} / \mathrm{L}$; potassium, $5.3 \mathrm{mEq} / \mathrm{L}$; chloride, 102 $\mathrm{mEq} / \mathrm{L}$; carbon dioxide content, $27.7 \mathrm{mEq} / \mathrm{L}$; calcium, 10.6 $\mathrm{mg} / \mathrm{dL}$; serum phosphorus, $5.6 \mathrm{mg} / \mathrm{dL}$; BUN, $18 \mathrm{mg} / \mathrm{dL}$; and creatinine, $0.8 \mathrm{mg} / \mathrm{dL}$

The patient's mother reported that she herself had no history of medication, tobacco, ethanol, or illicit substance use. She said she had not participated in any fad diet or dietary eccentricities. Sweat chloride testing done on the mother yielded a value of $2.5 \mathrm{mEq} / \mathrm{L}$. Serial determinations of the mother's breast milk sodium concentration yielded a value of $47 \mathrm{mEq} / \mathrm{L}$ on the child's $13 \mathrm{th}$ day of life, $35 \mathrm{mEq} / \mathrm{L}$ on the 14 th day of life, 20 
$\mathrm{mEq} / \mathrm{L}$ on the 16 th day of life, $18 \mathrm{mEq} / \mathrm{L}$ on the $24 \mathrm{th}$ day of life, and $16 \mathrm{mEq} / \mathrm{L}$ on the 31 st day of life. Though the mother had continued to pump her breasts mechanically during her child's hospital stay, she expressed doubt that she would ever reinitiate breast-feeding for the child, even if such feedings were approved by the nephrology staff physicians.

The child continues to be followed up by the CHM nephrology and neurology services. At 18 months of age, her weight is $14.5 \mathrm{~kg}$ (well above the 95 th percentile). She has required repeated admissions for her seizure disorder, and she is on phenobarbital and clonazepam therapy for seizure control. Because any oral stimulation causes her to become extremely irritable, feeding is now accomplished virtually exclusively by means of a nasogastric tube. The child has nearly continuous horizontal nystagmus; she does not focus on objects, and she has considerable head lag, decreased proximal muscle tone, and increased distal muscle tone.

\section{Discussion}

The low sodium concentration and low renal solute load $(75 \mathrm{~m} 0 \mathrm{sm} / \mathrm{L})^{6}$ of normal human milk have been regarded as being somewhat protective against the development of hypernatremia in breast-fed neonates. The sodium concentration of normal breast milk has been shown to vary as the milk "evolves" from colostrum (milk in the first
5 days after birth) to transitional milk to mature milk (milk after 15 days). ${ }^{7}$ The sodium concentration of colostrum is $22 \pm 3 \mathrm{mEq} / \mathrm{L}$; that of mature human milk is $7 \pm 2 \mathrm{mEq} / \mathrm{L}$.

The Figure shows the marked contrast between this case and the expected changes seen in the sodium content of normal human milk. In the literature, the highest breast milk sodium concentration found in association with hypernatremic dehydration of an infant was $104 \mathrm{mEq} / \mathrm{L}$, measured on the 17 th postpartum day. ${ }^{3}$ That infant's serum sodium value at admission was $180 \mathrm{mEq} / \mathrm{L}$.

In the cases reported, there appears to be no relation between the degree of elevation of the breast milk sodium concentration and the serum sodium values for the infants on admission. ${ }^{2-5}$ Three reports $^{2,3,5}$ included follow-up breast milk determinations of sodium content, none made later than the 23rd postpartum day. In our case, the mother was followed up until the 31st day after birth. All cases showed modest decrements in the breast milk sodium values over time, but none returned to the normal levels seen for mature milk.

The mechanisms of elevated breast milk sodium outlined in Table 1 are not completely clear. Mastitis can give rise to an elevation in breast milk sodium concentration; indeed, care must be taken

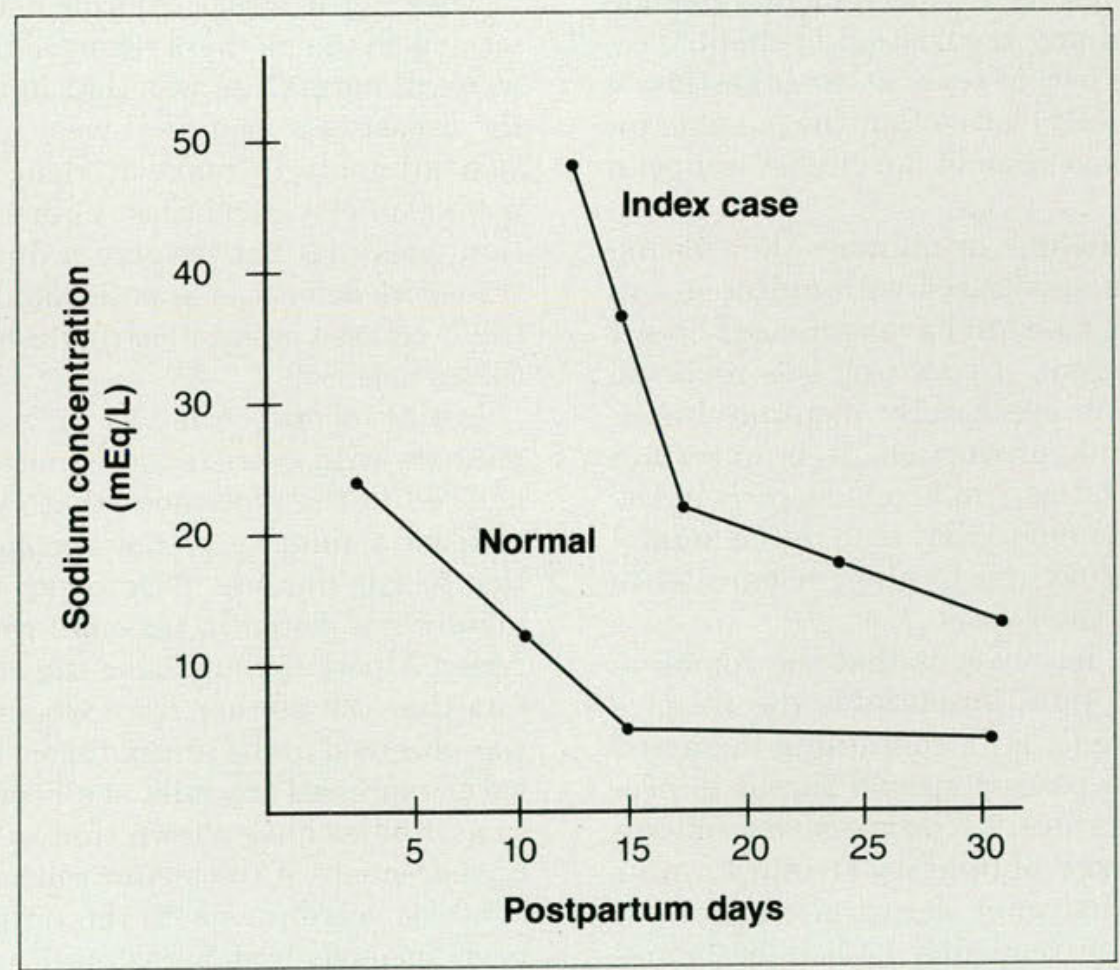

Figure. Sodium concentration in breast milk. 


\section{Table 1}

Mechanisms of Increased Breast Milk Sodium Concentration

- Mastitis or nipple lesions

- Maternal medications or diet

- "Drying" phase of lactation

- Maturational delay in milk

1. May be related to inadequate early lactose production

2. Is not related to a ductal sodium transport defect

3. Accompanying increased breast milk sodium concentration is not a sign of occult cystic fibrosis

to be sure that the mother's breast is cleaned and dried before sample collection to avoid spuriously high values. Lawrence ${ }^{1}$ believes that the proper collection technique should include taking a few milliliters of milk both before and after feeding and mixing the two samples together before testing and that, further, the milk from each breast should be checked separately. In contrast to this and in keeping with the manner of sample collection used in this case, Koo and Gupta's data ${ }^{8}$ showed no statistically significant difference in breast milk sodium concentrations with respect to either of these variables.

It is important that the mother's history include the contribution of any medication or dietary eccentricity, such as herbal teas, to the ingestion of a large exogenous salt load so that the possible influence on the composition of her breast milk can be assessed.

According to Schalm, ${ }^{9}$ in animals the "drying phase" of lactation, associated with a decrease in milk production, is noted to have increased breast milk mineral content. In two of the reported cases, ${ }^{2,4}$ the authors specifically mention diminished maternal milk production. It is uncertain whether decreased human milk volume early in lactation is similar enough to that seen in the animal model, as weaning occurs, to allow a parallel to be drawn between the two.

What is certain, however, is that the combination of diminished fluid intake plus the relative hypertonicity of breast milk containing increased amounts of sodium poses a special threat to neonates. These infants meet such excessive renal solute loads with large obligatory urinary water losses. ${ }^{5}$ The hypernatremic dehydration that ensues, along with its frequently associated neuronal desiccation, has been seen in tandem with sei- zures, hyperglycemia, focal neurologic deficits, and disseminated intravascular coagulopathy. ${ }^{3-5}$

Maturational delay in breast milk composition is an important concept to consider in attempting to understand mechanisms of elevated breast milk sodium levels because it serves to dispel any connection between this condition and cystic fibrosis. Sodium chloride and lactose concentrations in the milk combine reciprocally to maintain the milk's osmolarity at a level similar to that of the blood ${ }^{1}$; hence, any fall in lactose concentration would bring about an obligatory rise in the sodium concentration of the milk. It is therefore plausible that inadequate early lactose production by the breast may be related to the findings seen in these cases.

Lactose is manufactured in the Golgi apparatus of the mammary secretory cell, beginning late in pregnancy. An excellent discussion of this is offered by Lawrence. ${ }^{1}$ Progesterone plays a major role in control of mammary lactose production, with smaller and less clearly defined roles noted for prolactin and thyroxine. ${ }^{1}$ At the present time, however, insufficient understanding of lactose synthesis by the human breast clouds the precise role of progesterone as it relates to breast milk containing increased sodium concentrations.

The finding of an elevated breast milk sodium value is not a sign of occult cystic fibrosis in the mother. ${ }^{10}$ The sweat chloride determinations performed on the mothers reported in the literature ${ }^{3,5}$ were all normal, as was that in this case. Though the breast is a modified sweat gland, this discussion attempts to make it clear that the mechanism(s) of elevated breast milk sodium concentration does (do) not involve a ductal cell sodiumtransport defect, as is postulated to be a cause of the increased sweat electrolyte levels seen in cystic fibrosis. ${ }^{11}$

Initial reports on breast milk sodium values in mothers with cystic fibrosis noted elevated levels and led to the statement that cystic fibrosis was at least a relative, if not absolute, contraindication to safe nursing. ${ }^{10}$ However, the fact was ultimately uncovered in personal communication between Alpert's group ${ }^{10}$ and the original investigators that the mother from whom the breast milk was obtained in the initial report had never breastfed or expressed any milk at all before sample collection. Studies have shown that in the nonlactating breast, stasis of colostrum causes reequilibration of breast secretions with interstitial fluid, leading to erroneously high breast milk sodium concentration results. ${ }^{10}$ Several case reports analyzed and 
reviewed by Alpert's group ${ }^{10}$ now attest to the ability of mothers with cystic fibrosis to breast-feed successfully and safely, and to the fact that their breast milk sodium concentrations are within the normal range.

A distinctive clinical profile for these infants and their mothers can be derived from the literature. ${ }^{2-5}$ It was initially discussed in full by Rowland and colleagues $^{5}$ (Table 2). These infants are most often the products of uncomplicated term gestations, deliveries, and perinatal courses. Their mothers frequently are intelligent, caring women, well-motivated to breast-feed their babies and often primigravid. Barnes ${ }^{12}$ described five groups of feeding characteristics of breast-fed infants, forming a continuum from the aggressive "barracuda" infant to the more passive "rester." The infants under discussion do not seem to fit any of these patterns and frequently are described as being slow feeders with poor sucking.

Many of these infants are described as "good babies," some of whom sleep more than 20 hours a day. This false picture of apparent satisfaction on the part of the infant helps blind the parents to the ongoing dehydration and cachexia. As a result, the babies usually are not seen by the physician until they are 10 to 20 days old, often for unrelated problems such as constipation or cold skin. Diminished milk secretion has been noticed, as mentioned earlier, but this awareness, or concern, on the part of the mother is not a universal feature. Thorough medical investigation reveals no underlying organic disease in the infant, and all the babies described to date have thrived once they have been stabilized and given adequate nutritional support.

The clinical implications of this profile are important for the practitioner. Clearly, in few other situations in medicine can the counsel, teaching, and empathy of an interested, informed physician pay such large, direct dividends in terms of preventing significant neonatal morbidity. Many physicians and medical centers routinely schedule term newborns for the first office checkup at sometime between 2 to 4 weeks of age. The cases reported suggest that at least those mothers with nursing infants who fit the foregoing clinical profile to any degree should see the primary care provider earlier. This would permit earlier recognition of any evolving dehydration or malnutrition.

Such a visit should occur before the 10th day of life and, preferably, within the first week. Whether to test the infant's serum electrolyte levels would depend on the individual case and would,
Table 2

Clinical Profile of Hypernatremia in Infancy

- Infant usually is seen at 10 to 20 days of age with severe dehydration and cachexia

- Gestation, delivery, and initial neonatal course are uncomplicated

- Mother often primigravid, intelligent, and well motivated to breast-feed

- Infant is slow feeder with poor sucking; does not fit any of Barnes' five feeding characterizations of breast-fed infants ${ }^{12}$

- Infant is sleepy and quiet baby; "good baby"

- "Satisfied" infant contributes to lack of parental awareness of evolving cachexia

- Diminished milk secretion observed (but not in all cases)

- No underlying organic disease found in infant

- Infant thrives with adequate nutritional support

ideally, be dependent on the overall clinical picture of the infant-mother breast-feeding dyad. While studies are needed to help determine the incidence and prevalence of the problem, it is evident that greater physician awareness and more aggressive surveillance of selected cases can help avert a potentially disastrous situation.

Several aspects of the problem of elevated breast milk sodium concentration in association with hypernatremically dehydrated breast-fed infants still need clarification. Aside from defining the statistical parameters of the problem, the mechanisms governing elevation of human milk sodium content also need further research. Postellon ${ }^{13}$ hypothesized that loss of thyroxine in breast milk may be responsible, in whole or in part, for the transient postpartum hypothyroidism observed in some mothers. As mentioned earlier, thyroxine is known to exert an effect on human milk sodium concentration through its role in the regulation of lactose production in the human breast, even though that role is as yet ill defined. No study to date has yet looked at the relationship between maternal thyroid function studies and breast milk thyroxine and sodium concentrations.

Finally, but importantly, there are as yet no formal studies evaluating the nephrologic and neurologic outcomes of these children, despite the varied problems with these organ systems described in the literature. ${ }^{2-5}$

Promotion of breast-feeding is certainly to be encouraged, but physician awareness of its pitfalls serves to benefit us all as it permits infants at risk for complications to reach their fullest potential. 
1. Lawrence RA: Breast-Feeding: A Guide For the Medical Profession, ed 2. St Louis, CV Mosby Co, 1985, pp 54-61, 195, 275-296.

2. Anand SK, Sandborg C, Robinson RG, et al: Neonatal hypernatremia associated with elevated sodium concentration in breast milk. J Pediatr 1980;96:66-68.

3. Arboit JM: Breast-feeding and hypernatremia. J Pediatr 1980;97:335336.

4. Ghishan FK, Roloff JS: Malnutrition and hypernatremic dehydration in two breast-fed infants. Clin Pediatr 1983;22:592-594.

5. Rowland TW, Zori RT, Lafleur WR, et al: Malnutrition and hypernatremic dehydration in breast-fed infants. JAMA 1982;247:1016-1017.

6. Cole CH (ed): The Harriet Lane Handbook, ed 10. Chicago, Year Book Medical Publishers Inc, 1984, p 338.

7. Macy IG: Composition of human colostrum and milk. Am J Dis Child 1949;78:589.

8. Koo WWK, Gupta JM: Breast milk sodium. Arch Dis Child 1982;57:500502.

9. Schalm OW, Carroll EJ, Jain NC: Bovine Mastitis. Philadelphia, Lea \& Febiger, 1971, p 131.

10. Alpert SE, Cormier AP: Normal electrolyte and protein content in milk from mothers with cystic fibrosis: An explanation for the initial report of elevated milk sodium concentration. J Pediatr 1983;102:77-80.

11. Behrman RE, Vaughn VC (eds): Nelson Textbook of Pediatrics, ed 12. Philadelphia, WB Saunders Co, 1983, pp 1086-1087.

12. Barnes GR Jr, Lethin AN Jr, Jackson EB, et al: Management of breast feeding. JAMA 1953;151:192-199.

13. Postellon DC: Transient post-partum hypothyroidism, letter. Ann Intern Med 1978;88:431-432.

The manuscript assistance of Ms Robin Ledesma and of Ronald Grifka, MD, and the inspiration of mentor Ashok P. Sarnaik, $M B, B S$, are gratefully recognized.

From the department of pediatrics, Michigan State University College of Osteopathic Medicine, East Lansing.

Reprint requests to Dr Peters, assistant professor of pediatrics, department of pediatrics, Michigan State University College of Osteopathic Medicine, West Fee Hall, East Lansing, MI 488241316. 


\section{AMERICAN OSTEOPATHIC ASSOCIATION HOTEL RESERVATION APPLICATION 94th Annual Convention and Scientific Seminar}

NOVEMBER 12-16, 1989

ANAHEIM, CALIFORNIA

\section{HOTELS REQUIRE RESERVATIONS PRIOR TO OCTOBER 2, 1989 - MAIL EARLY}

PLEASE INDICATE YOUR PREFERRED HOTEL (CHECK ONE) AND MAIL THIS FORM TO:

AOA HOUSING BUREAU
\% ANAHEIM VISITORS \& CONVENTION BUREAU
P.O. BOX 4270
ANAHEIM, CALIFORNIA 92803

INDICATE THREE CHOICES BY WRITING 1, 2, or 3 IN THE APPROPRIATE BOXES (Preference Being \#1)

THE ANAHEIM HILTON \& TOWERS (Headquarters)

777 Convention Way

Anaheim, CA 92802 (714) 750-4321

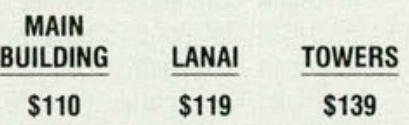

Single/Double
Suites

Standard- $1 \frac{1}{2}$ wide parlor

Standard-Double wide parlor

Lanai-Double wide parlor

Towers-Double wide parlor

Lanai-Triple wide parlor

\begin{tabular}{c} 
ONE-BEDROOM \\
\hline$\$ 275$ \\
$\$ 350$ \\
$\$ 425$ \\
$\$ 500$ \\
$\$ 650$
\end{tabular}

TWO-BEDROOM

$\$ 400$

$\$ 475$

$\$ 550$

$\$ 625$

$\$ 775$

\section{HYATT REGENCY ALICANTE}

100 Plaza Alicante

Garden Grove, CA 92640 (714) 971-3000

Single/Double

$\$ 88$

Suites

\section{QUALITY HOTEL \& CONFERENCE CENTER}

616 Convention Way

Anaheim, CA 92802 (714) 750-3131

Single/Double

Suites

One/Two-Bedroom

\section{INN AT THE PARK}

1855 South Harbor Blvd.

Anaheim, CA 92802 (714) 750-1811

Single/Double ............................ \$ 92

Suites

One-Bedroom

\$180-up

Two-Bedroom

\$260-up

\section{HOLIDAY INN - ANAHEIM}

1850 South Harbor Blvd.

Anaheim, CA 92802 (714) 750-2801

Single/Double ............................. \$ 75

Suites

One-Bedroom ............................ $\mathbf{\$ 1 5 0}$

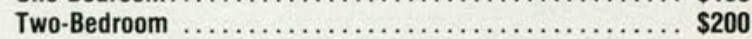

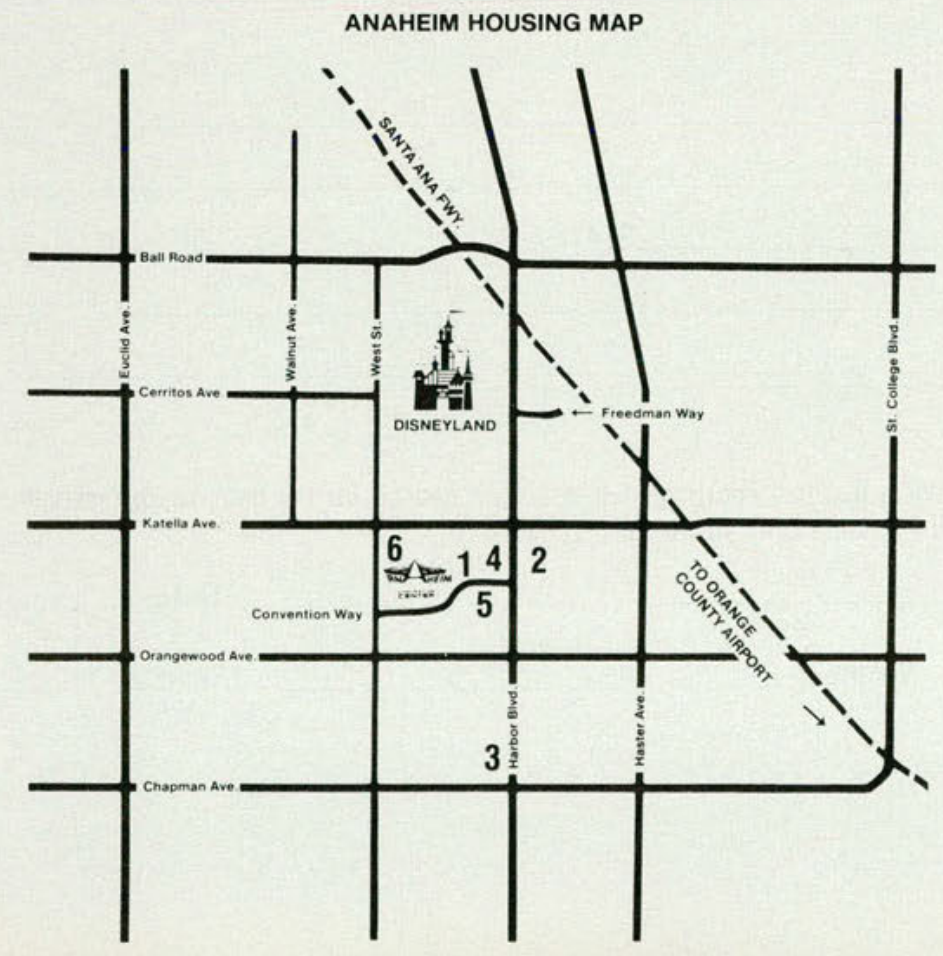

1. Anaheim Hilton

2. Holiday Inn

3. Hyatt Regency Alicante

4. Inn at the Park

5. Quality Hotel

6. Anaheim Convention Center 


\section{IMPORTANT INFORMATION}

1. Please complete this form in detail and mail it to the AOA HOUSING BUREAU, \% ANAHEIM VISITORS \& CONVENTION BUREAU, P.O. BOX 4270, ANAHEIM, CA 92803.

2. Do NOT send your reservations to the American Osteopathic Association's Central Office or to the hotel. MAIL THIS FORM DIRECTLY TO THE AOA HOUSING BUREAU, \% ANAHEIM VISITORS \& CONVENTION BUREAU - WITH REQUIRED DEPOSIT.

3. Check out time is 12:00 Noon, therefore, rooms may not be available until 3:00 p.m.

4. All reservations will be processed on a first-come, first-served basis and must be received by the AOA HOUSING BUREAU by October 2 , 1989. You will receive a confirmation directly from the Housing Bureau.

5. All hotels REQUIRE AN $\$ 80.00$ DEPOSIT, per room, to guarantee reservations. Make checks payable to the AOA Housing Bureau or complet the credit card information on the bottom of this form.

6. Please complete this form in detail. Incomplete forms will delay room assignments.

7. The hotel must be notified in writing of any room cancellations at least 72 hours in advance.

8. Registration, exhibits and didactic sessions will be held at the Anaheim Convention Center.

\section{PARTICIPATING GROUPS:}

American Academy of Osteopathy

American College of General Practitioners in Osteopathic

Medicine and Surgery

American College of Neuropsychiatrists

American College of Osteopathic Emergency Physicians

American College of Osteopathic Internists

American Osteopathic Academy of Addictionology

American Osteopathic Academy of Sclerotherapy, Inc.

American Osteopathic Academy of Sports Medicine

American Osteopathic College of Allergy \& Immunology American Osteopathic College of Dermatology American Osteopathic College of Pathologists American Osteopathic College of Preventive Medicine American Osteopathic College of Rehabilitation Medicine American Osteopathic College of Rheumatology, Inc. Auxiliary to the American Osteopathic Association Research Conference

(The Association of Osteopathic State Executive Directors is also meeting in conjunction with the AOA Convention.)

HOTEL CHOICES: (1)

(2)

TYPE OF ACCOMMODATION: (Please Check One)

\section{SINGLE}

\section{DOUBLE}

SUITES: 1 BDRM 2 BDRM

OTHER:

ARRIVAL DATE:

DEPARTURE DATE:
(3)

NAMES OF ALL OCCUPANTS OF ROOM (Please Print)

1.

2.

3.

TIME:

TIME:

\section{SEND CONFIRMATION TO: (Please Print)}

NAME:

ADDRESS:

CITY: STATE: ZIP:

TELEPHONE (Area Code):

\section{CREDIT CARD AUTHORIZATION}

The AOA Housing Bureau and assigned hotel are authorized to use this information to assess a deposit for my hotel room reservation. This deposit is not refundable unless reservations are cancelled 72 hours prior to arrival.

CARDHOLDER'S SIGNATURE:

DATE: 
The \#1 prescribed allergy in the U.S. and worldwide

\section{NO ANTIHISTAMINE}

- OLD OR NEW

IS MORE EFFECTIVE

Maximum efficacy - proven in 30 double-blind clinical studies ${ }^{1-5}$

Fast onset of action-most patients experience significant relief within 1 hour, ${ }^{6+}$ maximum efficacy in 3-4 hours h** $^{* *}$

Efficacy maintained with through-the-season use ${ }^{8-10}$

Unmatched patient preference $-77 \%$ of patients who started on Seldane and obtained another prescription in the category refilled that prescription with Seldane.

(Based upon a 1986 nationwide study of 640 patient members of prepaid group benefit plans.)

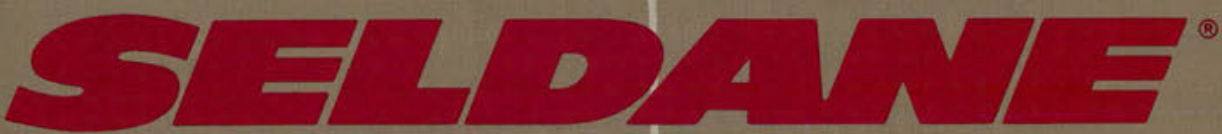

(terfenadine) $60 \mathrm{mg}$ tablets BID

for seasonal allergic rhinitis

The ideal profile for fast, on-the-job relief

- Based upon worldwide prescription and distribution information (1986-1988) - data on file

$t$ In most hay fever patients $(55 \%)$

** In studies utilizing the histamine-induced skin wheal test.

C) 1989, Merrell Dow Pharmaceuticals Inc.

Before prescribing Seldane, please see Brief Summary of Prescribing Information,

which appears on the reverse side. 


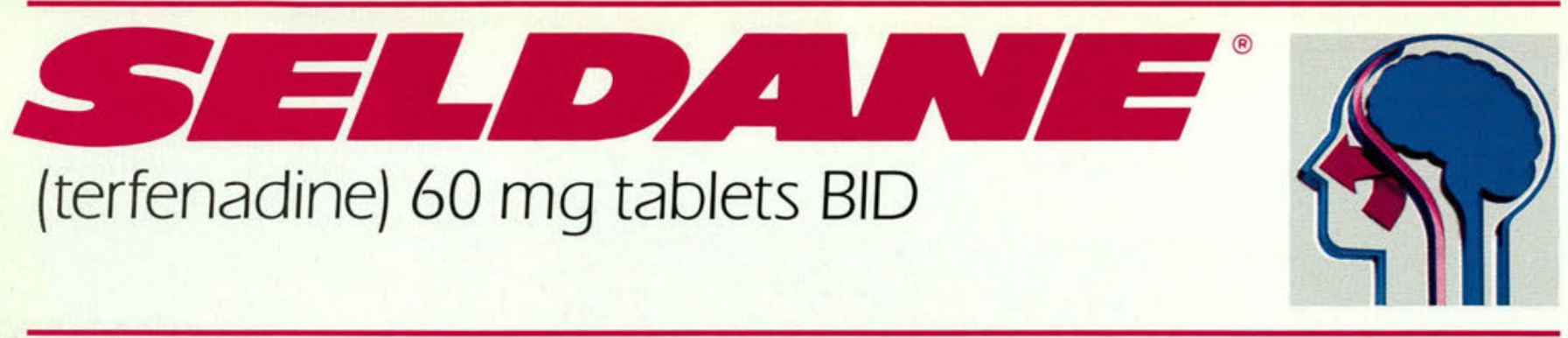

\section{- Fast, unsurpassed relief \\ - Efficacy maintained in through-the-season use - B.i.d. dosing for high patient compliance - High patient preference \\ - Lets patients stay alert so they can perform at their best}

\section{Seldane ${ }^{\circledR}$ (terfenadine) $60 \mathrm{mg}$ Tablets \\ BRIEF SUMMARY}

CAUTION: Federal law prohibits dispensing without prescription.

DESCRIPTION

Seldane (terfenadine) is available as tablets for oral administration. Each tablet contains $60 \mathrm{mg}$ terfenadine. Tablets also contain, as inactive ingredients: corn starch, gelatin, lactose, magnesium stearate, and sodium bicarbonate.

INDICATIONS AND USAGE

Seldane is indicated for the relief of symptoms associated with seasonal allergic rinitis such as sneezing, rhinorrhea, pruritus, and lacrimation.

CONTRAINDICATIONS

Seldane is contraindicated in patients with a known hypersensitivity to terfenadine or any of its ingreSeldane is
dients.

PRECAUTIONS

Information for patients

Patients taking Seldane should receive the following information and instructions. Antihistamines are before starting Seldane therapy, since the drug should be used in pregnancy or lactation only if the potential beneetit justifies the potential risk to retus or baby. Patients should be instructed to take Seldane


medication in
from children.

Carcinogenesis, mutagenesis, impairment of fertility

Oral doses of terfenadine, corresponding to 63 times the recommended human daily dose, in mice for 18 months or in rats for 24 months, revealed no evidence of tumorigenicity. Microbial and micronucleus test assays with terfenadine have revealed no evidence of mutagenesis.

Reproduction and fertility studies in rats showed no effects on male or female fertility at oral doses of up to 21 times the human daily dose. At 63 times the human daily dose there was a small but significant post-implantation losses were observed, which were judged to be secondary to maternal toxicity.

Pregnancy Category $C$

There was no evidence of animal teratogenicity. Reproduction studies have been performed in rats at doses 63 times and 125 times the human daily dose and have revealed decreased pup weight gain and survival when terfenadine was administered throughout pregnancy and lactation. There are no adequate and well-controlled studies in pregnant women. Seldane should be used during pregnancy only if the

Nonteratogenic effects survival in rats given doses 63 times and 125 times the human daily dose throughout pregnancy and lactation. Effects on pups exposed to Seldane only during lactation are not known, and there are no adequate and well-controlled studies in women during lactation.

Pediatric use

Safety and effectiveness of Seldane in children below the age of 12 years have not been established. General

Consideration should be given to potential anticholinergic (drying) effects in patients with lower airway disease, including asthma.

ADVERSE REACTIONS

Experience from clinical studies, including both controlled and uncontrolled studies involving more than of a few days up to six months. The usual dose in these studies was $60 \mathrm{mg}$ twice daily, but in a small number of patients, the dose was as low as $20 \mathrm{mg}$ twice a day, or as high as $600 \mathrm{mg}$ daily.

in controlled clinical studies using the recommended dose of $60 \mathrm{mg}$ b.i.d.. the incidence of reported prescribed to reduce allergic symptoms. Patients should be questioned about pregnancy or lactation reduction in implants and at 125 times the human daily dose reduced implants and increased potential benefit justifies the potential risk to the fetus.

Seldane is not recommended for nursing women. The drug has caused decreased pup weight gain and 2.400 patients who received Seldane, provides information on adverse experience incidence for periods

adverse effects in patients receiving Seldane was similar to that reported in patients receiving placebo. (See Table below.)

ADVERSE EVENTS REPORTED IN CLINICAL TRIALS

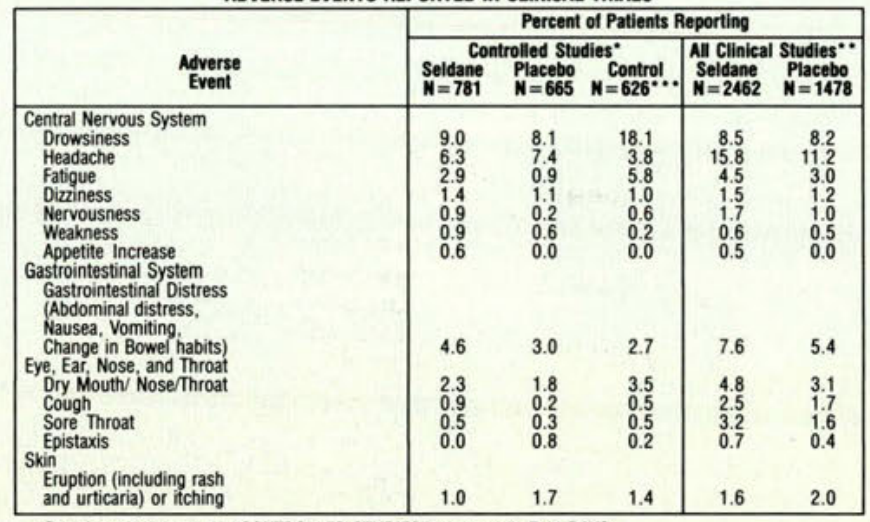

$\therefore$ "Duration of treatment in "CONTROLLED STUDIES" was usually 7-14 DAYS.

$\because$ Duration of treatment in "ALL CLINICAL STUDIES" was up to 6 months.

-CONTROL DRUGS: Chlorpheniramine (291 patients), d-Chlorpheniramine (189 patients), Clemastine (146 patients)

In addition to the more frequent side effects reported in clinical trials (See Table), adverse effects have been reported at a lower incidence in clinical trials and/or spontaneously during marketing of Seldane that warrant listing as possibly associated with drug administration. These include: alopecia, (hair loss or thinning), anaphylaxis, angioedema, arrhythmia (including ventricular tachyarrmythmia), bronchospasm, confusion, depression, galactorrhea, hypotension, insomnia, menstrual disorders (including dysmenorrinea), musculoskeletal symptoms, nightmares, palpitation, paresthesia, photosensitivity. prolonged OT interval, seizures, sweating, syncope, tachycardia, tremor, urinary frequency, and visual disturbances. In clinical trials, several instances of mild, or in one case, moderate transaminase elevations were seen in patients receiving Seldane. Mild elevations were also seen in placebo treated patients. Marketing experiences include isolated reports of jandice cholestatic hepatitis, and hepatitis: in most cases available information is incomplete. In neither the clinical trials nor marketing experience is a causal relationship of liver abnormalities to Seldane use clear.

OVERDOSAGE

Information concerning possible overdosage and its treatment appears in Full Prescribing Information. DOSAGE AND ADMINISTRATION

The usual dosage for adults and children 12 years and older is $60 \mathrm{mg}$ (1 tablet) twice daily.

Product Information as of June, 1988

MERRELL DOW PHARMACEUTICALS INC.

Subsidiary of The Dow Chemical Company

Merrell Dow

Y352D

References: 1. Kemp JP, Buckley CE, Gershwin ME, et al: Multicenter, double-blind, placebo-controlled trial of terfenadine in seasonal allergic rhinitis and conjunctivitis. Ann Allergy 1985:54:502-509 2. Backhouse CI, Brewster BS, Lockhart JDF, et al: Terfenadine in allergic rhinitis. A comparative trial of a new antihistamine versus chlorpheniramine and placebo. Practitioner 1982:226:347-348, 351. 3. Buckley CE, Buchman E, Falliers CJ, et al: Terfenadine treatment of fall hay fever. Ann Allergy 1988:60:123-128. 4. Melillo G. D'Amato G. Zanussi C. et al: A multicentre controlled trial of terfenadine, dexchlorpheniramine, and placebo in allergic rhinitis. Arzneim-Forsch/Drug Res 1982:32:1202-1203. 5. Data on file, MERRELL DOW PHARMACEUTICALS INC., Cincinnati, Ohio 45215. 6. MurphyO'Connor JC. Renton RL, Westlake DM: Comparative trial of two dose regimens of terfenadine in patients with hay fever. J Int Med Res 1984:12:333-337. 7. Hutthe KJ. Renftle G. Barraud N, et al: Inhibitory activity of terfenadine in histamine-induced skin wheals in man. Eur J Clin Pharmacol 1977:12:195-199. 8. Kemp JP, Falliers CJ, Fox RW, et al: A multicenter, open study of the non-sedating antihistamine, terfenadine (Seldane\%), in the maintenance therapy of seasonal allergic rhinitis. Ann Allergy 1988:60:349-354.9. Krause LB, Shuster S: The effect of terfenadine on dermographic wealing. Br J Dermatol 1984:10:73-79. 10. Simons FR. Watson WT. Simons KJ: Lack of subsensitivity to terfenadine during long-term treatment. J Allergy Clin Immunol 1988:82:1068-1075. 